\title{
PENNSYLVANIA PUBLIC SERVICE LAW
}

No act of assembly has been placed upon the statute books of Pennsylvania for many years so important to the people of Pennsylvania, and to the corporations serving the public, as the one known as "The Public Service Company Law," and approved by the Governor July 26th, 1913. The act is most skillfully drawn, contains little, if any, ambiguity, and would seem to be free from successful attack upo the ground of a violation of any constitutional provision.

It is to be assumed that the act is a composite of similar statutes in other states, with some improvements and additions. It is farreaching in its terms, provides a definite plan for the government of public service corporations, and is apparently intended to correct alleged evils in the relations existing between such companies and the public.

It is not intended to exhaustively consider the act in all its details, but rather to furnish a guide to its contents, helpful to those interested in the statute.

The statute applies to all corporations engaged in any of the following kinds of business within the state (Art. I, Sec. 1):

Artificial gas, baggage transfer, bridge, canal, common carrier, dining car, electricity, express, ferry, grain elevator, heating, incline plane, natural gas, pipe line, Pullman car, railroad, refrigerating, sewage, stage line, street railway, telegraph, telephone, tunnel, turnpike, water, water power, wharf.

The act does not apply with respect to any business transacted or property owned outside the commonwealth.

The act also applies to all persons engaged for profit in any of the kinds of business above enumerated within the commonwealth, but does not apply to a producer of electricity, gas, power, steam heat or water, for his sole use or for the use of his tenants, and not for sale to others. (Art. I, Sec. 1.)

Nor does the act extend to any matters which, under the Federal Constitution, the Congress of the United States has the exclusive power to regulate. (Art. I, Sec. 1.)

\section{MUNICIPALITIES.}

The act does not apply to municipalities, except as is specifically provided by the act (Art. I, Sec. 1). Those provisions are as follows: 
No municipality may acquire, construct or begin to operate any plant for serving the public within the municipality, when a company for the same purpose is already serving the public therein, without the approval of the Public Service Commission (Art. III, Sec. 3 (d) ).

But when a municipality does apply for this approval, it is to be given only if and when the Commission shall determine that such approval is necessary or proper for the service, accommodation, convenience or safety of the public; its certificate therefor being called a "Certificate of Public Convenience" (Art. V, Secs. 18 and 19).

The act also provides that a municipality is not prevented from operating such a plant in existence when the act takes effect, January 1,1914, or from completing one in process of construction before that date, or from extending a plant into municipal territory not then being supplied by a public service company (Art III, Sec. 3 (d)).

This is one of the most important provisions of the statute, in that it prevents future municipal rivalry of an existing public service company, when the Commission determines that such a company is furnishing proper service at fair rates.

When a municipality is engaged in furnishing a service of the kind or character of public service companies, it is required to keep the same system of accounts, and accessible to the Commission, as is required from such companies, and also to file with the Commission the same reports, records, maps, information, etc. (Art. Ir, Sec. 1 (i), Art. V, Sec. 15).

No contract or agreement between a public service company and a municipality shall be valid unless approved by the Commission (Art. III, Sec. 11). It is also provided that while the act does not take effect until January 1,1914, this section does take effect from the time of the approval of the act, July 26th, 1913 (Art. VI, Sec. 54). Before such a contract is made the company may apply to the Commission, upon notice to the municipality, for its declaration of the terms and conditions upon which it will grant its approval thereof (Art. III, Sec. 11). In order that these provisions may be constitutional they can be held to refer only to contracts made since the approval of the act.

\section{EXERCISE OF CORPORATE FRANCHISES.}

Before taking up the act more specifically, it is of value to state that the statute expressly provides that every public service 
company shall be entitled to the full enjoyment and exercise of all the prior powers and franchises lawfully possessed by it, except as is otherwise expressly provided in this act; all rights, duties and limitations provided by the act, and the exercise or enforcement thereof, being subject to the provisions of the Federal and State constitutions applicable to the company (Art. III, Sec. 12).

\section{DUTIES OF PUBLIC SERVICE CORPORATIONS.}

We now discuss the duties imposed by the act upon all public service companies, their control by the Commission, and the manner of the enforcement of such duties. Those duties are placed here under the following heads: Service; Rates, Tariffs and Schedules of Rates; Rules and Regulations; Accounting and Reports. For brevity, the word "company" is used herein to include every corporation subject to the act.

\section{SERVICE.}

This term is defined by the statute to include all acts done, things furnished, and facilities used by the company in the performance of its duties to its patrons, employees and the public (Art. I, Sec. 1).

The word "Facilities," as defined in the act, includes all the plant, equipment and property of the company used by it in its business; the items thereof being set forth with great particularity (Art. I, Sec. 1).

The company must furnish and maintain just, reasonable and adequate service to its patrons, through proper and safe facilities, and under the reasonable regulations of the Commission (Art. II, Sec. 1 (a); Art. V, Sec. 1).

It is also required to make such repairs, alterations and improvements in or to its service and facilities as are reasonable and necessary for the accommodation or safety of the public, and its employees (Art. II, Sec. 1 (c); Art. V, Sec. 1).

The Commission is given full power to supervise and regulate the adequacy and safety of the plant of the company, and also the service rendered by it; and when the Commission, after a public hearing and upon notice to the company, shall determine that its service or facilities are inadequate, or that the latter are unsafe, it shall specify what is adequate, safe and reasonable, and 
with such specifications the company must comply (Art. V, Secs. 1 and 2).

The Commission may also, in like manner, establish a reasonable standard of facilities and service and require the company to conform thereto; and it may require the company to make such changes or improvements in its facilities or service as shall be reasonably necessary for the accommodation, convenience and safety of its customers and employees (Art. V, Sec. 15).

\section{RATES.}

The term "Rates" includes fares, tolls, charges, prices, and all compensation demanded or received by the company (Art. II, Sec. 1.(b) ; Art. III, Sec. 1 (a) ).

The act provides that a company must furnish its service at reasonable rates and in conformity with the reasonable orders of the Commission (Art. II, Sec. 1 (b); Art. III, Sec. 1 (a)); and the Commission is given power to inquire into and regulate the rates of the company (Art. V, Sẹc. 1).

Whenever the Commission shall decide, after a hearing, that the rates are unjust, unreasonable or inadequate, or are unjustly discriminatory or unreasonably preferential, then the Commission shall determine what are the maximum, just and reasonable rates, to be thereafter charged by the company (Art. V, Sec. 3 ).

It is important to note the word "inadequate," as applied to the rates of the company. This would seem to indicate that the Commission has power to raise the rates when they are found to be inadequate. Under what circumstances this power will be exercised it is not now possible to state, as it remains for the future determination of the Commission. It may be applied to a company whose rates have been put upon an unremunerative basis to destroy the business of a rival, as has been held by similar bodies in other states, and it may be exercised to prevent a company from furnishing service to one class of customers, e.g. a municipality, at such a rate as to require the company to charge a higher rate to another class to maintain its earnings.

The company may not receive a greater or less sum from any consumer than it charges any other consumer for a like and contemporaneous service under substantially similar conditions (Art. III, Sec. 8 (a) ); nor may the company give any unreasonable preference to any consumer or locality, nor subject any particular 
person or locality to any undue or unreasonable prejudice or disIdvantage (Art.III, Sec. 8 (b) ).

As to preferences against localities, the statute is probably intended to prevent a difference in rates when the service is to different communities or in different sections of the same municipality, under like conditions; but the saving language of "undue or unreasonable" preferences or disadvantage might permit a company to make a difference in rates when there is a difference in location, for various reasons. Among these could be suggested localities where an extraordinary expense is necessary to make the service, or there was a scarcity of customers, or they are located in widely separated places.

When the Commission has determined the fair rates of the company, and a rate has been collected after January 1, 1914, which is found to be unjust, unreasonable or discriminatory, or is in excess of the tariffs of the company in effect when the service was rendered, or is in violation of the orders of the Commission, then when clamages have been actually sustained by the customer, and upon his petition, the Commission shall determine the amount of such damages, and issue what is called an "Order for Reparation"; and if the company does not pay them within the time limited by the order of the Commission, the customer to whom the damages have been awarded may sue therefor in any court of common pleas, wherein the order made by the Commission shall be regarded as prima facie evidence of the facts stated in the order, and that he is justly entitled to the amount claimed. This means that the burden of proof is upon the company to prove that the order is unjust, or the amount directed to be paid is unreasonable (Art. V, Sec. 5).

The customer must complain to the Commission within two years from the time when the alleged unjust rate was collected, and suit must be brought in the court within one year after the date of the Order for Reparation; nor can any suit be brought by him in any court with respect to alleged unjust rates until after the matter has been first determined by the Commission (Art. V, Sec. 5).

Whenever required by the Commission, the company shall file with it a tariff or schedule showing its rates, and shall post and publish the same in any of its offices open to the public, and where payment of rates is made by the customers, and also in such other places as may be required by the Commission; such schedules to 
be so posted that they may be conveniently inspected by the public. So, also, must it post with its. rates all the rules and regulations of the company affecting its rates (Art. II, Sec. 1 (d) ).

After January 1, 1914, no company can furnish any service until it shall have filed and posted its tariffs and schedules, as above provided (Art. III, Sec. 7), and the Commission is given full power to prescribe the forms for such tariffs and schedules (Art. V, Sec. 16).

While the act does not take effect until January 1,1914, there is a special provision that these schedules must be filed with the Commission when required by it after October 1, 1913. It would also seem that the schedule of rates and rules and regulations of the company must be posted in the office of the company by October 1, 1913 (Art. VI, Sec. 54). There is a little ambiguity at this point in the act, and it is probable that the intention of the language there used is that while the tariffs and schedules must be filed by January Ist, next, yet, as their form is to be determined by the Commission, it is probable that no penalty would fall against the company if these tariffs and schedules were not posted and filed before January 1, 1914, and when required by the Commission.

The company can make no change in its filed and posted rates, except after thirty days' notice to the Commission, and the public, plainly stating the exact changes to be made, and whether an increase or decrease, and when they go into effect; to be poster in some place where the schedule of rates is posted. The Commission may allow changes in the schedules upon less than thirty days' notice, but no rates which have been determined by the Commission can be changed or discontinued by the company within three years after such determination without the approval of the Commission upon thirty days notice to the public of the proposed changes, and given in the posted tariffs and schedules. When a company shall charge a rate in excess of a prior established rate a certificate of the excess shall be given to the customer when required by the Commission (Art. II, Sec. 1 (f); Art. V, Sec. 4).

It seems clear that the company may collect the new rates established by it in cases where rates have not been theretofore established by the Commission, but the excess over the old rates may be collected by the customer if the Commission shall thereafter declare the excess to be unreasonable and unjust. 
Whenever the Commission has notice of any change in the posted tariffs and schedules of the company it may hold a public hearing and make investigation as to the propriety of the proposed change, and may make such order with respect thereto as it may determine. At such hearing the burden of proof is upon the company to show that an increased rate is just and reasonable (Art. $\mathrm{V}$, Sec. 4).

When the company has posted and filed its tariffs and schedules, neither the company nor any of its officers shall be liable to any penalty or prosecution for collecting any rate or enforcing the rules of the company, when they are contained in such schedules, even if the Commission subsequently finds the rate to be unreasonable, etc. (Art VI, Sec. 41); but this exemption from penalty does not relieve the company from returning to the customer the excess rate he may have theretofore paid (Art. V, Sec. $5)$.

Where any company jointly acts or connects with any other public service company in the performance of any service, the joint tariffs and schedules of rates must also be posted and filed, when so required by the Commission. Provided, that such joint tariffs and schedules need be filed and posted by but one of the companies, the other company filing evidence of its concurrence therein (Art. II, Sec. 1 (e); Art. V, Sec. 3).

When companies shall disagree upon the division of joint rates between them, or their division is unreasonable, discriminatory or preferential, the Commission may fix the proportion to which each shall be entitled (Art. V, Sec. 10).

The company may establish a sliding scale of raics, and also with the consent of the Commission, "a scale of charges, subject to automatic adjustment, in relation to the dividends to be paid to the stockholders," and it may participate, to the extent permitted by the Commission, in the additional profits which will be afforded by economics, efficiencies or improvements in methods of service (Art. III, Sec. 1 (a)).

It may also employ suitable and reasonable classification of its service, patrons and rates; which classifications may "take into account the nature of, the use, and quantity used, the time when used, the purpose for which used, the kind, bulk, value, and facility of handling of commodities, and any other reasonable consideration" (Art. III, Sec. 1 (b)). 
The company may require the payment of rates in advance, or the making of reasonable minimum payments and deposits to secure future payments, and it may allow discounts for prompt payment of rates, or impose penalties for failure to pay promptly; provided that all of these are reasonable, and apply equally without discrimination to all customers under like conditions and similar circumstances (Art. III, Sec. 1 (c)).

\section{RULES AND REGULATIONS.}

The company may have reasonable rules and regulations, subject to existing laws and this act (Art. III, Sec. I (c) ); and they may be supervised by the Commission to make them just and reasonable (Art. V, Sec. 2). These rules and regulations must be posted and filed with the schedule of rates, as already stated (Art. II, Sec. 1 (d) ). So, also, must the joint rules, regulations and contracts of participating or connecting companies be filed and posted (Art. II, Sec. 1 (e)).

\section{ACCOUNTING.}

The company is required to keep such systems of accounts and records in conducting its business as shall be prescribed by the Commission; it may not carry any charges in an operating account which should be charged to capital account, nor vice versa, and shall carry a reasonable depreciation account, if required by the Commission (Art. II, Sec. 1 (i); Art. V, Sec. 15).

The company must also keep its books, accounts and records in an office within the Commonwealth (Art. II, Sec. $1(j)$ ).

It must also submit to the Commission, when required, all its maps, books, records, etc., in aid of any investigation by the Commission, or in aid of the determination of the value of its property, and for like purposes must furnish the Commission with all such other information as it may require (Art. II, Sec. 1 (k), and Art. V, Sec. 15).

Power is also given the Commission to inspect the plant of the company, as also its books, papers and all its effects, including its reports to any department of the Commonwealth or any municipality (Art. V, Sec. 23).

The Commission is given authority to compel the attendance of witnesses, and the production of books, papers, etc., of the company by subpœna (Art. V, Sec. 24). 
ISSUANCE OF STOCKS, BONDS, ETC.

The company is required to report to the Commission, when required by it, the disposition and application of the proceeds of its stocks, bonds, notes, etc., and may not use such proceeds for any purpose other than that returned in said report (Art. II, Sec. 1 (1), and Art. V, Sec. 22).

The company may issue stocks, bonds, etc., only for money, labor done, or money or property actually received, in accordance with the present constitutional requirements, and all other issues are declared to be void (Art. III, Sec. 4 (a)).

The company may apply to the Commission for a Certificate of Valuation to the effect that these constitutional provisions have been complied with for all issues of stocks, bonds, etc., made after January 1, 1914; the application to certify the amount to be issued, the purpose thereof, and such other information concerning the same as may be required by the Commission, and in such form as it may prescribe (Art. III, Sec. 4 (a) ). Such Certificate of Valuation shall not be taken as requiring the Commission, in any subsequent valuation of the property of the company to ascertain the amount to be paid the company for its property, to fix a valuation sufficient to yield a return to the holders of such securities; nor shall such Certificate of Valuation be deemed to require the Commission, in subsequently determining the rates to be charged by the company, to provide a rate which shall be sufficient to yield a return upon such securities (Art. V, Sec. 21).

When application is made to the Commission for its approval of any matter, not including rates for which other provision is made, such applications being enumerated in Art V, Sec. 18, it shall hold a public hearing, and shall have access to the company's property, books, records, etc., and shall make such examinations, valuations, etc., as it deems necessary; and in giving its approval of the application it shall issue a certificate to be known as its Certificate of Public Convenience (Art. V, Secs. 19 and 23).

Unless the company has applied to the Commission for, and there shall have been granted by it, a Certificate of Valuation, the company shall file with the Commission, on or prior to the issuance of the stocks, bonds, notes, etc., payable more than twelve months after their date, a Certificate of Notification, showing in the form required by the Commission:

I. The toal amount thereof. 
II. The amount outstanding prior to the date of the certificate, the amount retired, the amount undisposed of, and whether held in the treasury of the company or pledged, and, if pledged, the terms and conditions of such pledge.

III. The amount to be issued and the purposes of the issue; whether to be sold or pledged; the terms of sale or pledge thereof, and, if for other than money, an accurate description of the property to be received therefor.

IV. The amount thereof remaining unissued.

$V$. If of stock, the par value thereof, and the number of outstanding shares previously issued.

VI. The preference given the holders of such shares, and the maturity of the bonds, notes, etc., with the rate of interest, the conversion right if any, and the price at which the shares or securities may be redeemed (Art. III, Sec. 4 (b)).

When securities which are pledged or held in the treasury are subsequently sold a further Certificate of Notification shall be filed in the form stated (Art. III, Sec. 4 (c)). Such Certificate of Notification shall be signed by the fiscal officer of the company, and is open to such inspection and publicity as the Commission may deem to be for the public interest and welfare (Art. III, Sec. 4 (d) ).

Attention is called to these two certificates: The one the Certificate of Valuation, the other the Certificate of Notification, for two purposes: First, it is to be noted that if the Certificate of Valuation is given before the stocks and bonds are issued, then no further act of the company with respect thereto is required, while the Certificate of Notification must be filed before or when the stocks and bonds are issued. Second, there seems to be no -provision in the act requiring any approval by the Commission of the Certificate of Notification, while the application for a Certificate of Valuation presupposes an approval by the Commission of the issue of stocks and bonds, because otherwise the Certificate of Valuation would not be given. The importance of this lies in the fact that under the provisions of Section 18 of Article $V$ the approval of the Commission is to be based upon a public benefit. This is the exact language, "when application shall be made to the Commission by any public service company for any approval under any of the provisions of this act $* * *$ such approval; in each and every such case or kind of application, shall be given only if and when the said Commission shall find or determine that the 
granting or approval of such application is necessary or proper for the service, accommodation, convenience or safety of the public" (Art. V, Sec. 18).

As an application for a Certificate of Valuation comes within this clause, then a public benefit alone will warrant its isuance. It would seem to be wiser, therefore, for the company to proceed by the Certificate of Notification plan, concerning which there is apparently no approval to be asked or required. This question may hereafter be otherwise decided, but it seems to be clear as it is stated here, and it is certainly important. It may also be controlled by financial reasons: e. $g$., the requirements by bankers of a Certificate of Valuation.

It is declared to be unlawful for a company to capitalize its franchise rights or powers in excess of the amount it has paid the commonwealth, or any municipality as the consideration for the grant thereof (Art. III, Sec. 6 (a) ). This must mean that it can issue no stocks or bonds in this respect beyond the amount it paid to the commonwealth to secure its charter, or to a municipality for any grant, license or permission issued to the company.

Nor may the company issue any stocks or bonds upon merger beyond the aggregate value of the merged properties, or any additional sum paid in cash, and the value of property or labor contributed; nor may a company capitalize any lease or contract of sale (Art. III, Sec. 6 (a)).

Nor may any reorganized company make any issue of stocks, bonds, etc., beyond the value of the property of the reorganized company, or money paid the commonwealth or the municipality for its franchises or privileges, and the additional money or property contributed (Art. III, Sec. 6 (b) ). In both these cases the company may apply to the Commission to determine all these values (Art. III, Secs. 6 (a) and (b) ).

Nor can any public service company after January 1, 1914, acquire a controlling interest in the stocks, bonds, etc., of any other such company in Pennsylvania without the approval of the Commission; but it may acquire less than the controlling interest therein without such approval. However, this does not affect any such acquisition theretofore made, and when the company has acquired the controlling interest in such securities prior to January 1,1914 , it may thereafter acquire the remainder thereof without the approval of the Commission (Art. III, Sec. 6 (c) ). 
No Certificate of Notification or of Valuation, nor anything in this act, nor any order, finding, decree or act of the Commission, shall in any manner affect the invalidity, if any, of the stocks, bonds, etc., issued by a public service company prior to January 1 , 1914 (Art. III, Sec. 4 (d) ).

The Commission is empowered, either upon its own motion or upon complaint, to investigate and, after a hearing, determine whether any company has, after January 1,1914, made any issue of stocks, bonds, etc., in violation of this act, and, if so, then to certify the record of their hearing and determination to the Attorney General to institute legal process to enforce the provisions of the act, and to restrain the company from completing any unlawful issue of stocks, bonds, etc., or from continuing such acts (Art. V, Sec. 14).

It is also provided that the Commission may withhold from the public any facts or information obtained in the course of its investigations (Art. V, Sec. 26).

\section{VALUATION OF PROPERTY.}

Authority is given the Commission to determine the fair value of the property of every public service company. In doing this it may determine every fact which in its judgment has any bearing on such value. Among other things it may take into consideration:

I. The original cost of construction, particularly with reference to the amount expended in the existing and useful permanent improvements.

II. The market value of the stocks and bonds of the company.

III. The probable earning capacity of the property under rates prescribed by statute, ordinance or other municipal contract, or fixed or proposed by the Commission.

IV. The items of expenditure of the company for obsolete equipment and construction, as the circumstances and the historical development of the enterprise may warrant.

$V$. The reproduction costs of the property, based upon the fair average price of materials, property and labor.

VI. The developmental and going concern value of the company.

To these, and to any other elements of value, the Commission shall give such weight as may be just and right in each case (Art. V, Sec. 20 (a) ). 
The Commission may also revalue the property of the company from time to time, and ascertain the value of new construction, extensions and additions (Art. V; Sec. 20 (b) ).

It may also establish reasonable rules with respect to the preparation of valuations, the forms therefor, the inventories, statements and proofs of original cost, and other matters and information in connection therewith (Art. V, Sec. 20 (c)).

All hearings by the Commission for any kind of valuation shall be public, and the Commission may subpœna and examine witnesses and compel the production of books, papers, etc., and may make physical examinations of the property to be valued, and of the company's books, records, etc. (Art. V, Sec. 21).

After the determination of the valuation, the Commission may grant a rehearing, and from its final decision an appeal lies to the Court of Common Pleas of Dauphin County, and therefrom to the Supreme Court (Art. V, Sec. 21; Art. VI, Secs. 14, 17 and $30)$. Further consideration of the matter of appeals is discussed later under the subject of Procedure.

It is provided that the issuing by the Commission of any Certificate of Valuation or of Public Convenience, or any other of its acts, shall not revive or validate any lapsed, invalidated or void rights, powers or franchises of a company, or enlarge such rights, powers or franchises; the Certificate of Valuation being deemed to certify only to the legality of stocks, bonds, etc., issued (Art. V, Sec. 21).

These provisions as to valuations and with respect to what may be considered therein, and the basis therefor, are exceedingly important and seem eminently fair. It is to be particularly noted that the systems of valuation provided by the act are by no means rigid, but cover a great variety of plans, ranging from cost of construction, etc., to market value of the stocks and bonds of the company.

ORGANIZATION OF NEW COMPANIES, ETC.

The consent of the Commission is required:

(a) Before a new public service company can be incorporated (Art. III, Sec. 2 (a));

(b) Or such a company can exercise any right or franchise under any ordinance or municipal contract (Art. III, Sec. 2 (b)) ;

(c) For the renewal of the charter of any public service company, or to obtain additional franchises or powers by any amendment to its charter (Art. III, Sec. 3 (a)); 
(d) For a foreign public service company to be licensed in Pennsylvania (Art. III, Sec. 3 (b) );

(e) For any public service company to sell, lease or merge its property or franchises to or with any other company or person (Art. III, Sec. 3 (c) );

(f) For any municipality to acquire, construct or operate any plant to furnish service to the public of the kind already being served by a company within the municipality; provided the municipality has not prior to January 1,1914, begun to construct such a plant in that territory (Art. III, Sec. 3 (d) ).

But in all these cases the approval of the Commission is to be given only when it shall determine that the granting of the application therefor is necessary or proper for the service, accommodation, safety or convenience of the public (Art. V, Sec. 18).

\section{FURTHER REQUIREMENTS FROM A PUBLIC SERVICE CORPORATION.}

The company must file with the Commission, when it so requires, copies of all its contracts with any person, corporation, municipality, State or Federal Government, in relation to its publice service (Art. II, Sec. 1 (g)).

It must also file with the Commission reports containing any facts, information or accounts prescribed by the Commission, and as to companies subject to the Interstate Commerce Commission, copies of all reports filed therewith (Art II, Sec. 1 (h); Art. V, Sec. 25).

The company must give immediate notice to the Commission of the happening of any accidents in the operation of its property or service, whereby injury or death has resulted. Such reports shall be in detail and in such manner as the Commission may require, but they are not open to public inspection and cannot be admitted in evidence in any action for damages growing uut of the accident (Art. II, Sec. $1(x)$ ).

It must also obey all the lawful orders and regluations of the Commission (Art. II, Sec. $1(y)$ ).

The consent of the Commission must be had for the crossing of the facilities of one company by those of another company, or the relocation, change or abolition of crossings; and this consent is called a Certificate of Public Convenience (Art. III, Sec. 5; Art. V, Sec. 12). The term "Facilities," as we have already seen, includes every portion of the property of a public service company 
(Art. I, Sec. 1); hence these provisions as to crossing apply to every such company.

After January 1, 1914, it will not be required to obtain the consent of a court or municipality with respect to any such crossing, this matter being exclusively within the jurisdiction of the Commission, subject to appeal from its findings to the Court of Common Pleas of Dauphin County (Art. V, Sec. 12; Art. VI, Sec. 17).

Likewise, the Commission may regulate the safeguarding of crossings; it may order any existing crossings to be relocated or altered, and may determine the damages therefor, and who shall be liable to pay for the same (Art. V, Sec. 12).

The company must also obey all the lawful orders of the Commission regulating the manner in which crossings of the facilities of public service corporations are to be constructed, operated and protected (Art. V, Sec. 12).

The subject of crossings is considered more at length under the next heading.

Hereinbefore we have directed attention to the provisions of the act respecting all classes of public service corporations. We now discuss those portions applicable only to certain kinds of companies.

\section{RAILROAD COMPANIES, STREET RAILWAY COMPANIES, COMMON CARRIERS.}

The term "Railroad" includes every railroad, other than a street railway, by whatsoever power operated, for public use in the conveyance of passengers or property, or both, with all its plant, equipment, etc.; and whether the corporation is the owner, lessee or operator of any railroad within the commonwealth (Art. I, Sec. 1).

The term "Street Railway" includes every railway, by whatsoever power operated, for public use in the conveyance of passengers or property, or both, including its facilities, plant and equipment; and being mainly or in part located upon, over, above, below, across, through or under, any street, avenue, road, highway, bridge or public place; and whether the corporation is the owner, lessee or operator of any street railway within the commonwealth (Art. I, Sec. 1).

The term "Common Carrier" includes all common carriers, whether corporations or persons, engaged for profit in the con- 
veyance of passengers or property, or both, between points within the commonwealth, on land or water (Art. I, Sec. 1).

All railroads, street railway companies and common carriers must furnish a reasonably sufficient number of cars, trains, etc., and run them with such motive power as may be reasonably required, in the conveyance of all such passengers and property as may seek or be offered to it for such conveyance, and with such sufficient frequency, at such reasonable times, and to and from such stations or points, as the Commission may reasonably require; and, upon like requirement, to change the time schedules for trains, cars, etc., and generally make such other arrangements and improvements in their service as the Commission may require (Art. III, Sec. 1 (m); Art. V, Sec. 17).

A railroad, or other common carrier engaged in the transportation of freight, shall furnish, upon reasonable request of shippers, sufficient cars, etc., required to transport freight offered for that purpose. In case at any particular time there is a shortage in cars, motive power, etc., sufficient for all shippers, then to make lawful distribution of those available among the several applicants therefor, without discrimination between shippers or localities or competitive and non-competitive points, in accordance with the rules of the Interstate Commerce Commission. Its tariffs and schedules must show the method of distribution of cars, etc. (Art. II, Sec. 1 (n) ; Art. V, Secs. 1 and 17; Art. II, Sec. 1 (d) ).

But preference may always be given in the supply of cars, etc., for shipment of live stock or perishable freight (Art. II, Sec. 1 (n) ).

The Commission has power to regulate the location or abolition rs passenger and freight stations, etc., and the use and compensation for cars owned by others (Art. V, Sec. 1).

A railroad corporation, upon application of an owner or operator of any lateral railroad or private side track, and tendering freight for transportation, or of any consignee, shall construct, maintain and operate, at a reasonable place and upon reasonable terms, a switch connection with such lateral railroad or side track constructed for that purpose, when such switch connection is reasonably practicable, and can be put in with safety and will furnish sufficient business to justify its construction and maintenance (Art. II, Sec. 1 (o); Art. V, Sec. 1).

When such a lateral railroad or side track has been connected with a railroad, or it has been sold or leased to a railroad corpora- 
tion, any person or corporation may connect therewith, or use the same, upon payment of a reasonable proportion of its cost and maintenance, to be determined, if necessary, by the Commission; provided such connection and use may be made without unreasonable interference with its use by the party building, or now owning or leasing the lateral railroad, etc. (Art. II, Sec. 1 (o) ).

Whenever required by the Commission, a railroad or street railway company must construct a connection with the lines of other companies of the same character, where reasonably practicable and a continuous line of transportation can be formed, and cause the conveyance of persons and property between points within the commonwealth without interruption or delay, and the Commission may equitably apportion the cost of construction, maintenance and operation of such connection. But no such company shall be required to give the use of its tracks or terminal facilities to any other common carrier (Art. II, Sec. I (s); Art. V, Sec. 7).

These provisions as to connecting railroads do not apply to a street railway company engaged in the business of carrying passengers, and not transporting freight, or generally soliciting freight as a main branch of its business (Art. II, Sec. 1 (s) ; Art. V, Sec. 7).

Common carriers must cause the conveyance of passengers and property to be reasonably continuous, and without unreasonable interruptions or delay (Art. II, Sec. 1 (p)).

If necessary for the rendering of safe and adequate service, the Commission may regulate the switching, loading or unloading of cars, their weighing or billing, and the weighing of freight (Art. V, Sec. 17).

It may also regulate demurrage charges, baggage or package room charges and their transfer rates and charges, and, generally, to make such other arrangements and improvements in service and facilities as shall be reasonable, having regard to the needs of the public (Art. V, Sec. 17).

Where there are through routes and service, reasonable fares and rates shall be established; the Commission being given power to establish these through routes and joint rates, when not established by the railroads: provided that the Commission shall not require any railroad company, without its consent, to embrace in such route less than the entire length of its railroad and of any intermediate road operated by it, which lies between the termini of such proposed through route, unless to do so would make it 
unreasonably long as compared with another practicable through route, which would otherwise be established. The Commission may also, if necessary, fix the equitable apportionment and division of any joint rates (Art. V, Sec. 7 ; Art. II, Sec. 1 (s) ).

A street railway company, when required by the Commission for the accommodation, convenience or safety of the public, must transfer its passengers to or from another part of its system; and to this end make proper and convenient time schedules, as also with other connecting, etc., street railways (Art. II, Sec. 1 (r); Art. V, Secs. 1 and 6).

Power is given the Commission of routing lines of street railway companies under the provisions of the act of May 15th, 1895 (P. L. 65), or otherwise (Art. V, Sec. 1).

If necessary for safe and adequate service, the Commission may require all common carriers to revise and change their time schedules; to alter the running of trains, cars, etc., or change the routes of street railway lines or systems (Art, V, Sec. 17).

Whenever a common carrier receives freight for points in this state, it shall issue a bill of lading therefor, and shall be liable to the holder thereof for any loss to the property so shipped, whether on the line of the common carrier, or on any line over which such property passes (Art. II, Sec. 1 (q)).

No contract, receipt, rule or regulation shall exempt any common carrier from the liability above imposed; nor is the holder of the bill of lading deprived hereby of any existing remedy (Art. II, Sec. 1 (q) ).

When a common carrier, issuing a bill of lading, pays the holder thereof for loss of freight on another line, it is entitled to recover the amount so paid from the other company (Art. II, Sec. 1 (q)).

Whenever a shipper renders any service connected with the transportation of freight by a common carrier, the charge therefor shall be just and reasonable, and the Commission may determine what is a reasonable charge as a maximum for such service, as also what is a proper proportion thereof (Art. III, Sec. 1 (e) ).

When, as the result of a bona fide error, the full charges are not collected by a common carrier in the first instance, it may waive the collection of the balance, with the approval of the Commission (Art. III, Sec. 8 (a)).

The Commission may investigate the rates or interstate traffic facilities or service of common carriers within the state, and when it determines that they are unreasonable or unjustly discrimina- 
tory or preferential, or in violation of interstate commerce law, or in conflict with the rulings of the Interstate Commerce Commission, the Commission may apply for relief to the Interstate Commerce Commission, or may present the facts to that Commission (Art. V, Sec. 11).

It shall be unlawful for a common carrier to charge a greater compensation, in the aggregate, for the conveyance of passengers or freight of the same class for a shorter than a longer distance over the same line in the same direction, the shorter being included in the longer (Art. III, Sec. 9 (a)).

It may not charge a greater compensation as a through rate than the aggregate of the intermediate rates, without the consent of the Commission; but this does not authorize a charge for a shorter greater than a longer distance (Art. III, Sec. 9 (a)).

Nothing in this section prohibits common carriers from establishing reasonable zone systems of charges (Art. III, Sec. 9 (a) ).

No common carrier may charge less than established rates by means of false billing, classification, weight or other device (Art. III, Sec. 9 (b) ).

Excursion and commutation tickets may be issued at special rates, upon filing with the Commission and posting schedules thereof, as required for other rates (Art. III, Sec. 9 (b) ).

Common carriers may issue free passes, or passes at a discount, to its officers and employees (Art. III, Sec. 9 (b) ).

Upon filing them with the Commission, railroad corporations may enter into contracts with telephone, telegraph and express, or other railroad companies, for the exchange of service at free or reduced rates ( $\Lambda$ rt. III, Sec. 9 (b) ).

The tariffs and schedules of rates shall conform to those required by the Interstate Commerce Commission (Art. II, Sec. 1 (d) ).

\section{RAILROAD AND STREET RAILWAY CROSSINGS.}

Railroad and street railways must abice by the regulations of the Commission with respect to the manner in which their tracks cross those of other railroads or street railways, or the facilities of other public service companies, at grade, or above or below grade, or at any prescribed level (Art. II, Sec. 1 ( $t$ ); Art. V, Sec. 12).

They must also obey the regulations of the Commission as to crossing their tracks over highways at grade, or above or below 
grade. These regulations will also extend to the crossing of highways over the tracks of such companies (Art. II, Sec. 1 ( $t$ ); Art. V, Sec. 12).

The regulation of the Commission must be obeyed as to the manner in which crossings of tracks and highways shall be operated, maintained and protected, to the end that accidents may be prevented and the safety of the public promoted (Art. II, Sec. 1 (t); Art. V, Sec. 12).

They must also abide by the regulations of the Commission requiring alterations, relocations, renewals or abolition of such crossings, to prevent accidents (Art. II, Sec. 9 (t); Art. 5, Sec. 12).

No crossings over the tracks of other railroads or street railways, or over highways, may be constructed by any railroad or street railway corporation without the approval of the Commission, evidenced by its Certificate of Public Convenience (Art. III, Sec. 5; Art. V, Sec. 12).

When crossings are in process of abolition when the act takes effect, under an agreement with the municipality, such abolition may be proceeded with without obtaining the consent of the Commission (Art. III, Sec. 5).

Except as concerns crossings in process of abolition when the act takes effect, the Commission has exclusive power over all crossings to determine, in accordance with the plans prescribed by it, the manner of construction of such crossings and their operation, maintenance and protection, as also their relocation, alteration or abolition (Art. V, Sec. 12).

The compensation for damages to adjacent property owners sustained in the construction, relocation, alteration or abolition of all such crossings shall be determined by the Commission, and for the amount so ascertained the said owners are authorized, upon appeal from such determination, to sue the commonwealth (Art. $V$, Sec. 12).

Such compensation for damages, as well as the expense of the constructions, etc., of the crossings, shall be borne and paid by the corporations and municipalities, or by the commonwealth, in such proportions as the Commission may determine, in the absence of an agreement by all the parties respecting the same (Art. V, Sec. 12).

In prescribing the terms for the construction, etc., of crossings, and the proportionate contribution to the expense thereof, includ- 
ing damages to adjacent owners, the Commission may take into consideration the relative importance to the public of the services rendered by the companies, as well as the priority of location; provided that when any portion of such cost and expenses has been, or shall be borne by the commonwealth or a municipality, such portion shall not be taken into account by the Commission in fixing any valuation for any purpose under this act (Art. V, Sec. 12).

When the construction of a crossing requires a relocation, changes in, or the renewal of any adjacent structure, or other facilities, of any telegraph, telephone, gas, electric light, water or other public service corporation, such company shall, at its own expense, relocate, change or remove its structures or other facilities, in conformity with the order of the Commission (Art. V, Sec. 12).

Before the Commission shall make any final order relative to the construction, etc., of any crossing involving a public highway, an effort shall be made by it to reach an agreement with the municipality concerned, to determine the plans and specifications governing such crossing; failing which, the Commission shall exercise its exclusive powers with respect thereto (Art. V, Sec. 12).

The Commission may permit the companies, or the municipality, to do the work in connection with the crossing; otherwise the Commission shall have it done by contract (Art. V, Sec. 12).

The contractor may sue in the name of the Commission to collect the amount due him for the work from the companies or the municipality or the commonwealth, as may be determined by the Commission (Art. V, Sec. 12).

The Commission may recover by law, from the companies or the municipality, their respective proportions of the damages awarded to the owners of adjacent property, the amount so recovered to be paid to the State Treasurer for the improvement of the roads of the commonwealth (Art. V, Sec. 12).

\section{TELEGRAPH AND TELEPHONE COMPANIES.}

Telegraph and telephone companies must cause the transmission of despatches, messages or communications, to be reasonably continuous and without unreasonable interruption or delay (Art. II, Sec. $1(p))$. 
A telegraph company may be required by the Commission to connect its lines with those of another telegraph company, and thereupon it shall become the reciprocal duty of both companies, upon payment of the proper charges, to receive and despatch messages impartially and in good faith (Art. II, Sec. 1 (u); Art. $\mathrm{V}$, Sec. 8).

Telephone companies whose lines could form a continuous line of communication between different localities not reached by the lines of either alone, and could be made to do so by the construction of suitable connections between the lines at common points, for the transmission of conversation between different localities, must jointly arrange for the interchange and transfer of conversations at such common points when it can be reasonably done, and efficient service obtained without injustice to either company, and without substantial impairment or detriment to the service rendered by either company, and when necessity exists therefor, in order to supply through traffic communications between different localities not otherwise provided for by either company (Art. II, Sec. 1 (v); Art. V, Sec. 9).

In such cases a joint through traffic shall be operated over the connected lines under joint rules and at reasonable rates, the revenues therefrom to be equitably apportioned among the companies; both being within the control of the Commission (Art. II, Sec. 1 (v) ; Art. V, Sec. 9).

These two last paragraphs apply also to persons engaged in the telephone business (Art. II, Sec. I (v)).

The Commission has power to inquire into and regulate the service and charges for long and short transmission of messages and conversations by telegraph and telephone (Art. V, Sec. 1).

Telegraph and telephone companies, or persons engaged in like business, may not charge any greater compensation in the aggregate for the transmission of any message or conversation for a shorter than a longer distance over the same line in the same direction, the shorter being inclucled in the longer distance; but the Commission may, in special cases, authorize a less charge for a longer than a shorter distance under a specific order, and prescribing the extent of the relief (Art. III, Sec. 10).

Such companies cannot charge any greater compensation as a through rate than the aggregate of the intermediate rates; but this does not permit a charge as great for a shorter as a longer distance, subject to the powers of the Commission, as last above stated. (Art. III, Sec. 10). 
Telegraph and telephone companies may establish reasonable zone systems of charges (Art. III, Sec. 10).

The tariffs and schedules of rates shall conform to those required by the Interstate Commerce Commission (Art. II, Sec. 1 (d)).

Such companies may enter into contracts, to be filed with the Commission, with each other or with railroad or express corporations, for exchange of service at free or reduced rates (Art. III, Sec. 9 (b) ).

When application shall be made to the Commission by a telegraph or telephone company for the approval of the connection of their lines with those of any other such company, such approval shall be given only when the Commission shall determine that the granting thereof is necessary or proper for the service, accommodation, convenience or safety of the public (Art. V, Sec. 18).

When the construction of a crossing requires a relocation, changes in, or the removal of any adjacent structures or other facilities or any telegraph or telephone company, such company shall, at its own expense, relocate, change or remove the structures or other facilities in conformity with the order of the Commission (Art. V, Sec. 12).

\section{WATER, GAS AND ELECTRIC COMPANIES.}

The crossing of the facilities of one company by those of another, or the crossing of the facilities of a water, gas or electric company over a highway, are provided for by the act. The word facilities, as we have already seen, includes, as regards the companies named, their pipes, mains, poles and wires; hence, all such crossings, no matter where or with what companies, are under the control of the Commission (Art. III, Sec. 5; Art. V, Sec. 12). Reference may be had to the discussion of this subject more at length under the head of "Railroads, Street Railways and Common Carriers."

When any cross is made requiring a relocation, change or removal of any adjacent structure or other facility, of any water, gas or electric company, such company must relocate, change or remove its structures and facilities in conformity with the order of the Commission (Art. V, Sec. 12).

When water, gas or electricity is served over a meter, the company is required to have proper and approved apparatus to test 
and prove its accuracy, to be approved from time to time and marked by the Commission (Art. II, Sec. 1 (w)).

Whenever a consumer makes a written request for a test of a meter, it shall be had in his presence if he desires. If the meter is found to be accurate, within the Commission's rules, a reasonable fee to cover the cost of the test, to be fixed by the Commission by standing order, shall be paid by the consumer; otherwise it shall be borne by the company (Art. II, Sec. 1 (w)).

Heretofore, the Court of Common Pleas of the county where the company is located could compel a water or gas company to properly supply its customers, by enjoining the collection of its charges until the supply was pure and sufficient (Act April 29, 1874, Sec. 34, Proviso to Clause 3; Brymer v. Butler Water Co., $172 \mathrm{~Pa}$., 489). This proviso is now repealed, so that after January 1,1914 , the service of a water or gas company is exclusively within the control of the Commission, subject to appeal (Art VI, Sec. 51 ; Art. IV, Sec. 1; see also preceding title, "Service," pp. 4-5).

Likewise, this act repeals the second proviso of Clause 7 of Section 34 of the act of April 29th, 1874; so that after January 1,1914 , the courts have, $a b$ initio, no control over the rates of a water or gas company, but only on appeal, or where an Order for Reparation is sued out (Art. VI, Sec. 51; Art. V, Secs. 1 and 5; see also preceding subject under title of "Rates").

The body of Clause 7 of Section 34 of the act of April 29th, 1874 , referring to the purchase of the property of water and gas companies by the municipality of its location, is not affected by this act, except to require the consent of the Commission (Art. III, Sec. 3 (d), and probably cannot be against the companies, under the authority of Manheim v. Manheim Water Cc., 229 Pa., 177.

The act repeals the first proviso to Clause 7 of Section 34 of the act of April 29th, 1874, which provides that nothing contained in the section respecting the right of a municipality to purchase the works of a water or gas company, shall authorize a company incorporated under the provisions of that act, to construct water or gas works within the limits of the municipality, when such works shall have been constructed by the municipality, without the lawful consent of its authorities (Art. VI, Sec. 51). 
PROCEDURE BEFORE THE COMMISSION, ETC.

Every public service company is permitted to apply to the Commission by complaint, whenever it claims to be aggrieved by any ruling made by the Commission; and shall be entitled to a full and fair hearing thereon, and to all just and reasonable relief consistent with the rights and duties of the company (Art. III, Sec. 1 (d) ).

All hearings of the Commission shall be public, and governed by rules prescribed by it (Art VI, Sec. 1).

No person shall be excused from testifying or producing any books, or papers, on the ground that such testimony, books or papers would tend to criminate him, or subject him to penalty (Art. VI, Sec. 1).

But he shall not be prosecuted or be subject to any penalty, for or on account of any transaction concerning which he shall testify or produce books or papers. However, no person so testifying shall be exempt from prosecution for any perjury committed in so testifying; nor is any immunity given the company by reason of the exemption of the persons testifying (Art. VI, Sec. 1).

The Commission may require copies of books, etc., to be sent to it in any part of the state (Art. VI, Sec. 2).

Subpœnas for witnesses are to be signed by a member of the Commission, or its secretary; and may be served by any adult within the state (Art. VI, Sec. 2).

The fees for witnesses, and for the service of subpœnas, are fixed by the act (Art. VI, Sec. 2).

The costs, etc., in connection with any hearing, may be imposed by the Commission upon any party to the record, or divided between them (Art. VI, Sec. 2).

The aid of the courts to compel a witness to testify, or to produce books and papers may be invoked by the Commission (Art. VI, Sec. 3).

Fines are imposed upon an officer or director who shall absent himself to avoid a subpona, or destroy or conceal any books or papers (Art. VI, Sec. 4).

Any person, corporation, or municipality, complaining of the acts or omissions of a company in violation of this act or the orders of the Commission, may present a sworn petition to the Commission, containing a concise statement of the facts complained of. A copy thereof will be served upon the company, which it is to answer (Art. VI, Sec. 6). 
If the company satisfies the complaint within the time specified by the Commission, the petition shall be dismissed; otherwise the matter shall be heard, unless the Commission determines that there is not a reasonable ground of complaint. A full report of the case will be made by the stenographer of the Commission (Art. VI, Sec. 7).

The Commission may also proceed upon its own motion, and without a complaint, to investigate any such matter against the company (Art. VI, Sec. 8).

When the complaint or voluntary investigation is with respect to an alleged violation of an order of the Commission, and a hearing is had thereon, the burden of proof is upon the company. to show that the order has been complied with (Art. VI, Sec. 9).

The finding of the Commission shall be either dismissing the complaint, or directing the company to satisfy the complainant, as it may specify. Except in case of a complaint concerning rates, the complaint shall not be dismissed merely because of the absence of direct damages to the complainant (Art. VI, Sec. 10).

The finding of the Commission shall be in writing, and served upon the company, and the Commission may grant a rehearing and rescind or modify its former finding; but no application for a rehearing shall operate as a supersedeas, unless so directed by the Commission (Art. VI, Sers. 11, 12, 13, I4, 15 and 16).

Within thirty days after the filing of the finding of the Commission, or the refusal of an application for a rehearing, any party to the proceedings affected thereby, may appeal to the Court of Common Pleas of Dauphin County, which is given exclusive jurisdiction for that purposè.

But this does not apply to an Order for Reparation with respect to improper rates, for which an action lies in the common pleas of the county where the company is located, as hereinbefore stated (Art. VI, Sec. 17).

In cases concerning damages or compensation awarded under any of the provisions of the act; there may be a jury trial under Section 8, Article XVI of the Constitution, by an appeal to the court of the proper county (Art. VI, Sec. 17).

The appeal to the Common Pleas of Dauphin County shall be by petition setting forth the alleged errors, with a copy of the complaint and of the findings of the Commission, together with an affidavit that the appeal is not taken for delay, but because injustice has been done the appellant (Art. VI, Sec. 17). 
- In appeals from awards by the Commission for damages for property taken, where the Commission has power to apportion the amourit thereof among, or direct the payment thereof by any company or municipality, such company or municipality may intervene and be heard on the trial of the appeal, under the rules of the court where the appeal is pending (Art. VI, Sec. 17).

The Commission is to be notified of the appeal by the appellant, and is required to certify the whole record to the court, all costs therefor to be advanced by the appellant and to become part of the costs of the case (Art. VI, Sec. 18):

No appeal shall operate as a supersedeas unless so ordered by the court, after notice to the Commission and the other parties to the record; and a bond may be required from the appellant for such supersedeas (Art. VI, Sec. 19).

But every appeal by the company from any findings as to rates shall operate as a supersedeas upon filing a bond in an amount fixed, and with sureties approved by the court, conditioned for the repayment of any excess in the rates finally found against the company (Art. VI, Sec. 19).

Upon the petition of the Commission, the complainant before it may be added as a party defendant, and the court may permit any person or corporation to intervene, and to be addled as a party plaintiff, or defendant (Art. VI, Sec. 20).

The Commission shall file an answer to the petition for appeal, as may any other party to the record, when permitted so to do by the court, and thereupon the case is at issue and heard (Art. VI, Sec. 21).

Upon the hearing on appeal the court shall determine whether the order appealed from is or is not reasonable, and in conformity with law (Art. VI, Sec. 22).

Such order is prima facie reasonable, and the burden of proof is upon the appellant to show the contrary; the notes of testimony taken before the Commission to be considered by the court as the only evidence in the case (Art. VI, Sec. 23).

The decision of the court may be to affirm the order of the Commission; it may remand the record to the Commission for a reconsideration; or it may reverse the order, and dismiss the complaint or reverse the order so as to reinstate a dismissed compaint; and the court shall have full power to dispose of all costs (Art. VI, Sec. 24). 
No evidence shall be received at the hearing on appeal, but after-discovered evidence may be ordered by the court to be heard by the Commission, upon remanding the record to it for that purpose (Art. VI, Sec. 25).

All process shall be served, and the practice and rules of evidence shall be as in civil actions (Art. VI, Secs. 26 and 27).

Appeals from the order of the Commission shall take precedence upon the calendars of the court over all other civil actions, except election cases and suits for wages (Art. VI, Sec. 28).

When trial by jury is constitutionally secured, it shall remain inviolate on appeal, except it shall be taken to be waived upon appeal, unless reserved in such reasonable manner as the court may prescribe (Art. VI, Sec. 29).

An appeal from the final order of the court may be had to the Supreme Court by any party aggrieved (Art. VI, Sec. 30).

No injunction shall issue against an order of the Commission, except on notice to it and cause shown upon hearing; and therefor the Court of Common Pleas of Dauphin County is given exclusive jurisdiction, subject to appeal to the Supreme Court. Any order of the Commission shall remain in force until set aside, amended or modified. (Art. VI, Sec. 31).

Every company and its officers, etc., affected by any final order of the Commission, or any final order of the Court of Common Pleas of Dauphin County, or of the Supreme Court, shall comply therewith so long as they are in force (Art. VI, Sec. 32).

The Commission may institute proceedings against a company in its own name in the Court of Common Pleas of Dauphin County by injunction, mandamus or other legal process, to restrain any violation of the provisions of this act, or of the order of the Commission, or judgment or decree of the courts, or to enforce obedience thereto (Art. VI, Sec. 33).

So, also, may the Attorney General, in the name of the commonwealth, proceed in like manner against the company for any of the causes enumerated (Art. VI, Sec. 34).

If any company shall violate any of the provisions of this act, or omit to perform any duty therein enjoined, or shall fail to comply with any final order of the Commission, or any final judgment of the Court of Common Pleas of Dauphin County, or of the Supreme Court, the company shall pay to the commonwealth a fine of fifty dollars per day for every day in which it may be in default: but this time shall not be computed during an appeal 
where a supersedeas has been granted, or preliminary injunction awarded (Art. VI, Secs. 35 and 36).

Any officer who shall knowingly sign any stock certificate, bonds, etc., of a company, or any director who shall knowingly assent to the issue thereof, in vioation of this act or of the Constitution; or any officer or director who shall knowingly make or assent to any fase statement in any Certificate of Notification, shall be guilty of a misdemeanor, and subject to fine or imprisonment (Art. VI, Sec. 37).

Any officer or director of any company who shall knowingly make-or assent to the application of any stock, bonds, etc., or their proceeds, in violation of any statements or contrary to any purpose contained in the Certificate of Notification; or who shall knowingly make or assent to any false report or statement to the Commission; or a false statement, etc., as to the application of the proceeds of any stock, bonds, etc., shall be guilty of a misdemeanor, and subject to fine or imprisonment (Art. VI, Sec. 38).

Any person who shall knowingly fail to comply with any final order of the Commission, or of the court, shall be guilty of a misdemeanor, and subject to fine and imprisonment (Art. VI, Sec. 39).

Any company doing any act forbidden by this statute, or failing to perform anything required of it thereby, shall be liable to the person or corporation injured in the amount of damages thereby sustained; no liability for negligence, or recovery of penalties, being affected by this act (Art. VI, Sec. 40).

All suits, remedies, penalties, etc., provided for or accruing under this act, shall be cumulative (Art. VI, Sec. 42).

All fines and penalties shall be paid to the State Treasury, through the Secretary of the Commission (Art. VI, Sec. 43).

Any action to recover any penalty provided by this act, or any prosecution concerning any matter therein, must be brought within three years from the time when the liability arose; except in suits to recover for excess rates, hereinbefore provided to be brought within one year (Art. VI, Sec. 44; Art. V, Sec. 5).

\section{GENERAL PROVISIONS.}

In addition to the expressly enumerated powers given the Commission, it shall have full power and authority, and it is its duty, to enforce and carry out by its orders, etc., all the provisions of Articles II and III of the act relating to the duties and limitations, 
creation and powers of public service companies, and all other provisions of the act; with power to rescind or modify its orders, etc. (Art. V, Sec. 27).

The enumeration of the powers of the Commission shall not exclude any power which it would otherwise have under the act (Art. V, Sec. 28).

Except as otherwise provided, none of the powers or duties conferred upon the Commission, and none of its orders, etc., and none of the duties, powers or limitations conferred or imposed upon public service companies, or the performance or exercise thereof, shall be construed to impair the obligations, etc., of such companies under existing common or statutory law, and such obligations shall remain as heretofore (Art. V, Sec. 29).

Nothing in the act, except as otherwise provided, shall alter any existing rights of action, or remedies in equity; the provisions of this act being cumulative, and in addition to such rights of action. and remedies (Art. V, Sec. 29).

Nothing in the act shall impair the powers and duties of the Secretary of Internal Affairs in the supervision of railroads, canals, etc.; nor shall it deprive the Department of Health, or the Water Supply Commission, of any jurisdiction or powers vested in them by law (Art. VI, Sec. 45).

Copies of all official documents filed with the Commission, and of testimony and proceedings before it, when certified by its Secretary under its seal, shall be received in evidence as would the originals (Art. VI, Sec. 46).

Fees for copies of documents, etc., filed with the Commission, testimony, proceedings, reports of companies, etc., are fixed by the act (Art. VI, Sec. 47).

The Commission shall make an annual report to the Governor, showing:

1. A record of its meetings and an abstract of its proceedings;

2. Results of examinations or investigations made by it;

3. Statements, facts, etc., disclosing the actual workings of public service companies in their relation to the business and prosperity of the commonwealth, with such suggestions as to the general policy of the commonwealth, or the amendment of its laws with respect to such companies, as are appropriate;

4. Drafts of bills suggested by the Commission, and the reasons therefor; 
5. Such tables and abstracts of the reports of public service companies as it may deem expedient;

6. Statements of expenses of the Commissioners and of their appointees and employees (Art. VI, Sec. 48).

The act does not apply, except when specifically so provided, to commerce with foreign nations, or among the several states, except as permitted by the Constitution of the United States and the acts of Congress (Art. VI, Sec. 49).

The provisions of the act are severable one from another, and also as to public service companies, and the subject matters dealt with thereby (Art. VI, Sec. 50).

If any provision shall be judicially declared to be unconstitutional, as applicable to any particular company or subject matter, or otherwise, such holding shall not affect the validity of such provision as to other companies, or subject matters dealt with thereby, or the validity of the remaining provisions of the act; it being declared that the said provision or remaining provisions would have been enacted notwithstanding such judicial determination (Art. VI, Sec. 50).

The following acts are repealed, or amended:

The act appointing the Railroad Commission, etc., of May 31, 1907 (P. L. 337) ;

Sections $I$ and 2 of the act of June 4, 1883, (P. L. 72), to enforce the provisions of Article XVII of the Constitution relative to railroads and canals;

An act to provide the maximum car service charges, etc., approved May 24, 1907 (P. L. 229);

The provisos by Clauses 3 and 7 to Section 34 of the General Corporation Act of April 29th, 1874 (P. L. 73).

All acts inconsistent with or supplied by this act (Art. VI, Sec. 51).

The act to promote the safety of travelers, etc., approved June 19, 1911 (P. L. 1053), is amended in Section 9 by naming the Commission in place of the Railroad Commission, and it is to enforce the act (Art. VI, Sec.. 53).

The records, etc., of, and pending cases before, the Railroad Commission are to be transferred to the new Commission (Art. VI, Sec. 52).

\section{CONSTITUTION OF COMMISSION.}

It is created as an administrative body, to be known as "The Public Service Commission of the Commonwealth of Pennsyl- 
vania," with an official seal, and is authorized to become a party to legal proceeedings (Art. IV, Sec. 1).

The Commission shall consist of seven members, appointed by the Governor, with the advice and consent of the Senate. Each Commissioner shall be a resident and qualified elector of the commonwealth, and not less than thirty years of age (Art. IV, Sec. 2).

No Commissioner, or any officer or employee of the Commission, can occupy any official relation to any public service company or hold any other office of the commonwealth or any municipality, nor can they be engaged in any business the duties of which are incompatible with the duties of their offices, nor participate in any hearing in which they have any direct or indirect pecuniary interest, nor may they solicit or recommend to any company the appointment of any individual to office or employment (Art. IV, Sec. 12).

Their terms of office shall be four, five, six, seven, eight, nine and ten years, respectively, from July 1, 1913, and their successors shall be appointed for a term of ten years (Art. IV, Sec. 2).

One of the members of the Commission, and so to be designated by the Governor, shall be its chairman (Art. IV, Sec. 2).

Vacancies in the Commission shall be filled by the Governor for the residue of the term (Art. IV, Sec. 3).

A quorum shall consist of four members, who, for all purposes, including the making of any order or the ratification of an act done by one or more of the Commissioners, must act unanimously (Art. IV, Sec. 3).

No vacancy shall impair the right of a quorum of the Commissioners to exercise the rights and perform the duties of the Commission (Art. IV, Sec. 3).

The Commission may authorize any one Commissioner to make any investigation or hold a hearing; but no order, etc., made by him, shall become effective until approved by at least a quurom (Art. IV, Sec. 4).

The Commission shall have a Secretary, who shall keep a full record of all the proceedings, determinations, etc., of the Commission, and have the custody of its records, books, etc. Under its direction, he shall be the chief executive officer of the Commission, superintend its business, conduct its correspondence, give notice of its determinations, etc., and prepare papers, etc., for service; he may administer oaths in all proceedings before the 
Commission, and may designate a clerk, appointed by the Commission, to perform his duties in his absence (Art. IV, Sec. 5).

The Attorney General shall be, ex-officio, the general counsel of the Commission. He shall appoint two attorneys as counsel and assistant counsel, respectively, for the Commission, one of whom shall attend the hearings before the Commission, conduct the examination of witnesses and represent the Commission in the courts. They shall also assist the Attorney General in conducting mandamus, etc., proceedings for the enforcement of the orders of the Commission, and shall perform such other duties as it may require (Art. IV, Sec. 6).

The Commission may appoint a Marshal, who shall attend its hearings, preserve order, superintend service of subpenas, etc., (Art. IV, Sec. 7).

The Commission shall appoint an Investigator of Accidents to investigate the cause of any accident in connection with the operation of the property, facilities, etc., of any public service company, where any person shall have been killed or injured, or property destroyed, and make report thereof to the Commission. He shall also report to the Commission if any company has failed to give notice of the happening of accidents, etc., as prescribed by Article II, Section 1 (x) (Art. IV, Sec. 8).

Such reports, etc., of accidents shall not be open for public inspection, except by order of the Commission, and shall not be arlmitted in evidence for any purpose in any suit for damages growing out of the accident (Art. IV, Sec. 8).

The Commission has power to employ other officers, experts, itatisticians, inspectors, etc., necessary to carry out the provisions of the act (Art. IV, Sec. 9).

The act fixes the salaries of the Commissioners, Sceretary, Counsel, Marshal and Investigator of Accidents, and provides for their expenses in the performance of their duties, and for their audit and allowance (Art. IV, Secs. 10 and 11).

No company, its officers, etc., may offer to any member of the Commission, its officers or employees, any office or position, or give them any free passes or transportation, or any reduction in fares, to which the public is not entitled, or any present, etc. (Art. IV, Sec. 13).

If the Secretary, Marshal, Investigator of Accidents, or any employee of the Commission shall violate any of the provisions of this act, the Commission shall forthwith remove him from office; and the Governor, with the consent of the Senate, may 
remove any Commissioner, or any of the counsel to the Commission, for inefficiency, neglect of duty or misconduct in office, upon giving him a statement of such charges, and affording him a trial (Art. IV, Secs. 14 and 15 ).

Each Commissioner, the Secretary, Attorneys, Marshal, etc., shall qualify by taking the oath prescribed by Article VII of the Constitution (Art. IV, Sec. 16).

The principal office of the Commission shall be in Harrisburg, in rooms designated by the Board of Commissioners of Public Grounds and Buildings (Art. IV, Sec. 17).

The Commission, or a quorum thereof, shall hold meetings at least twice a month during the year at its principal office, and may hold meetings at any time, and at any place within the State (Art. IV, Sec. 18).

The act makes provision for supplying the Commission with books, stationery, furniture, printing, etc. (Art. IV, Sec. 19).

The office of the Commission at Harrisburg shall be open for business between 9 A. M. and 5 P. M. every business day in the year, and attended by one or more responsible persons designated by the Commission, or by its Secretary (Art. IV, Sec. 20).

WHEN THIS ACT GOES INTO EFFECT.

The act does not go into effect until January 1st, 1914, except that after October 1, 1913, every public service company must post its schedule of rates, and its rules and regulations, and, when required, file them with the Commission; and it is also provided that any contract between a public service company and a municipality made after the date of the approval of the act, July 26th, 1913, must be filed with the Commission to become valid (Art. VI, Sec. 54; Art. III, Sec. 11).

It can be said that this statute is fair and reasonable. Its provisions are far from being intemperate or tyrannical, and any company in Pennsylvania giving reasonable service at fair prices, and obeying the orders of the Commission, need fear no prosecution or attack thereunder. The Commissioners appointed under the statute are gentlemen of high standing and ability, and the Commonwealth is to be congratulated that the Governor has made such wise selections. After all, it is the Commissioners themselves with whom lies the fair adjudication of the statute, and the people of Pennsylvania, as well as the public service corporations, can be assured that their findings will be just and equitable.

Williamsport, $P a$.

C. LaRue. Munson. 